\title{
RESURVEY OF THE “BYRD” STATION, ANTARGTICA, DRILL HOLE
}

\author{
By D. E. Garfield and H. T. Ueda
}

(U.S. Army Cold Regions Research and Engineering Laboratory, Hanover, New
Hampshire 03755, U.S.A.)

\begin{abstract}
Anstract. The drill hole at "Byrd" station, which was completed in January 1968 to a vertical depth of $7063 \mathrm{ft}(2153 \mathrm{~m})$ below the top of the hole casing, was resurveyed in January 1975 to a vertical depth of $4835 \mathrm{ft}(\mathrm{r} 474 \mathrm{~m})$. Inclination and azimuth measurements were made with a Parsons multiple shot inclinometer and compared with the earlier measurements made during drilling. The results indicate a progressively increasing displacement with depth to a value of $51.2 \mathrm{ft}(15.6 \mathrm{~m})$ or about $7.3 \mathrm{ft} /$ year $(2.23 \mathrm{~m} /$ year $)$ at the $4835 \mathrm{ft}(\mathrm{r} 474 \mathrm{~m})$ level. The direction of movement relative to the surface varies from south-west at $300 \mathrm{ft}$ $(9 \mathrm{r} .5 \mathrm{~m})$ to north-east at $\mathrm{I} \mathrm{I}$ oo $\mathrm{ft}(335 \mathrm{~m})$ to east at $3368 \mathrm{ft}(\mathrm{I} \mathrm{O} 27 \mathrm{~m})$ to north-east at $4835 \mathrm{ft}(\mathrm{I} 474 \mathrm{~m})$, indicative of a complex twisting motion. An increase in accessible depth along the hole axis of $18 \mathrm{ft}(5.49 \mathrm{~m})$
beyond the 1969 depth was noted. No attempt was made to measure hole diameter or vertical strain. It is recommended that the hole be resurveyed in $3-5$ years if it is still logistically feasible, using a more up-dated inclinometer.
\end{abstract}

RÉsumé. Re-examen du forage de la station "Byrd" en Antarctique. Le forage de la station "Byrd" qui avait été achevé en janvier 1968 jusqu'à une profondeur verticale de 2 I $53 \mathrm{~m}$ sous le sommet de la foreuse, a été réexaminé en janvier I 975 jusqu'à une profondeur de $1474 \mathrm{~m}$. Des mesures d'inclinaison et d'azimut ont été faites avec un inclinomètre multiple de Parsons et comparées avec les premières mesures réalisées au cours du forage. Les résultats montrent un déplacement s'accroissant progressivement avec la profondeur jusqu'à une valeur de $15,6 \mathrm{~m}$ à $1474 \mathrm{~m}$ ou environ $2,23 \mathrm{~m} / \mathrm{an}$. La direction du mouvement par rapport à la surface varie du Sud-Ouest à $91,5 \mathrm{~m}$ au Nord-Est à $335 \mathrm{~m}$, à l'Est à $\mathrm{I} 027 \mathrm{~m}$ et au Nord-Est à $\mathrm{I} 474 \mathrm{~m}$, ce qui prouve un mouvement complexe de torsion. On a noté un accroissement de $5,49 \mathrm{~m}$ de la profondeur accessible le long de l'axe du forage depuis 1969 . On n'a pas essayé de mesurer le diamètre du trou ou les déformations verticales. On recommande de reprendre l'examen du forage dans les 3 à 5 ans si c'est encore réalisable du point de vue logistique, en utilisant un inclinomètre plus moderne.

Zusammenfassung. Neuvermessung des Bohrloches an der "Byrd" Station, Antarktika. Das Bohrloch an der "Byrd" Station, das im Januar 1968 bis zu einer vertikalen Tiefe von 2 I $53 \mathrm{~m}$ unter den Rand der Auskleidung niedergebracht worden war, wurde im Januar 1975 bis zu einer vertikalen Tiefe von $1474 \mathrm{~m}$ neu vermessen. Neigungs- und Richtungsmessungen wurden mit einem Mehrfach-Klinometer von Parsons vorgenommen und mit Messungen verglichen, die während des Bohrens stattfanden. Die Ergebnisse zeigen eine mit der Tiefe allmählich zunehmende Verlagerung bis zu einem Wert von ${ }_{5} 5,6 \mathrm{~m}$ bei $\mathrm{I}_{4} 474 \mathrm{~m}$ oder etwa $2,23 \mathrm{~m}$ pro Jahr. Die Bewegungsrichtung relativ zur Oberfläche schwankt von Südwest bei $9^{1}, 5 \mathrm{~m}$ über Nordost bei $335 \mathrm{~m}$, Ost bei 1 o27 m bis Nordost bei $1474 \mathrm{~m}$, ein Anzeichen für eine komplexe Torsionsbewegung. Es wurde eine Zunahme der erreichbaren Tiefe längs der Lochachse von 5,49 m über die Tiefe von 1969 hinaus beobachtet. Messungen des Lochdurchmessers oder der Vertikalspannung wurden nicht versucht. Es wird empfohlen, das Loch in $3-5$ Jahren wieder zu vermessen, wenn dies operationell noch möglich ist; dabei sollte ein modernes Klinometer verwendet werden.

\section{INTRODUCTION}

The drill hole at "Byrd" station (lat. $80^{\circ} 9^{1}$ ' S., long. $119^{\circ} 3^{I^{\prime}}$ W.) was completed in January 1968 to a vertical depth of $7063 \mathrm{ft}(2 \mathrm{I} 53 \mathrm{~m})$ below the top of the hole casing. Inclinometer measurements were obtained as drilling progressed during the $1967-68$ season with a Parsons single-shot inclinometer located at the upper end of the drill (Garfield, I968). Due to encountering water at the bottom of the ice and the accompanying problems, the hole became inaccessible beyond $5500 \mathrm{ft}(\mathrm{I} 677 \mathrm{~m})$ by the following year. Attempts to clear the hole were not successful in 1968-69 and resulted in the loss of the drill down hole. In I 969-70 the drill cable was cut off at a depth of $5067 \mathrm{ft}$ ( $1545 \mathrm{~m}$ ) along the hole axis and from the top of the casing.

In January 1975, the hole was resurveyed to a depth of $4835 \mathrm{ft}$ ( $1474 \mathrm{~m}$ ) below the top of the casing* with a Parson's multiple-shot inclinometer. Beyond this depth the range of the instrument was exceeded. Although a complete hole survey would have included hole diameter and vertical strain measurements, no attempt was made to obtain these as adequate techniques and equipment were not available.

\footnotetext{
* The top of the casing was approximately $45 \mathrm{ft}(\mathrm{r} 3.7 \mathrm{~m})$ from the 1975 snow surface.
} 


\section{Equipment}

The inclinometer used for this investigation was purchased from the Parsons Survey Co. several years ago and has been used in other bore holes in ice (Gow, r963; B. L. Hansen, personal communication). The position of a plumb bob and its magnetic bearing are photographically recorded on $10 \mathrm{~mm}$ film. A small electric-motor-driven mechanism within the unit is actuated from the surface to advance the film and energize the exposure bulbs. The graduated range of the instrument is $7^{\circ}$ but for this operation the calibration was extended to a range of $12^{\circ}$. Due to the magnetic compass, the unit cannot be used in the vicinity of ferrous materials such as inside the steel-cased portion of the drill hole. Conventional EastmanKodak Tri-X film, I $6 \mathrm{~mm}$ cut to Io $\mathrm{mm}$ was used for this operation. The camera and inclinometer assembly are shown in Figure I. Figure 2 shows the pressure-tight housing within which the instrument is mounted. A typical measurement photograph is shown in Figure 3 .

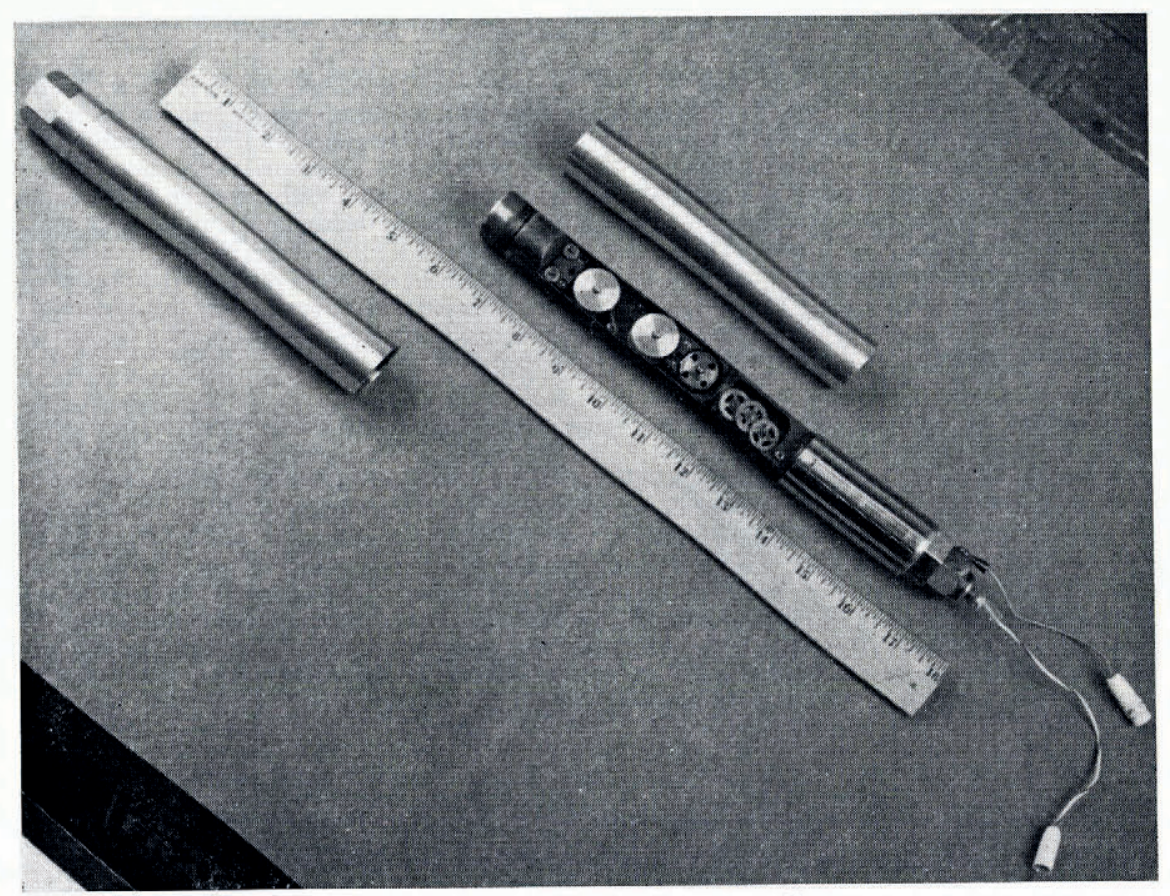

Fig. I. Inclinometer assembly showing $10 \mathrm{~mm}$ film camera.

An electro-hydraulic winch with 8 ooo ft (2 $439 \mathrm{~m})$ of seven-conductor armored electrical cable was used to raise and lower the housing in the hole. The average rate of raising and lowering was about $23 \mathrm{ft} / \mathrm{min}(7 \mathrm{~m} / \mathrm{min})$. An electronic footage counter measured the length of cable payed out.

\section{Procedure}

Prior to the measurement run, a dry run with the instrument housing was taken to determine the accessible hole depth and check the integrity of the housing. A depth along the hole axis of $5085 \mathrm{ft}$ ( $155^{\circ} \mathrm{m}$ ) from the top of the casing was noted, which was $18 \mathrm{ft}$ $(5.49 \mathrm{~m})$ beyond the 1969 depth. 


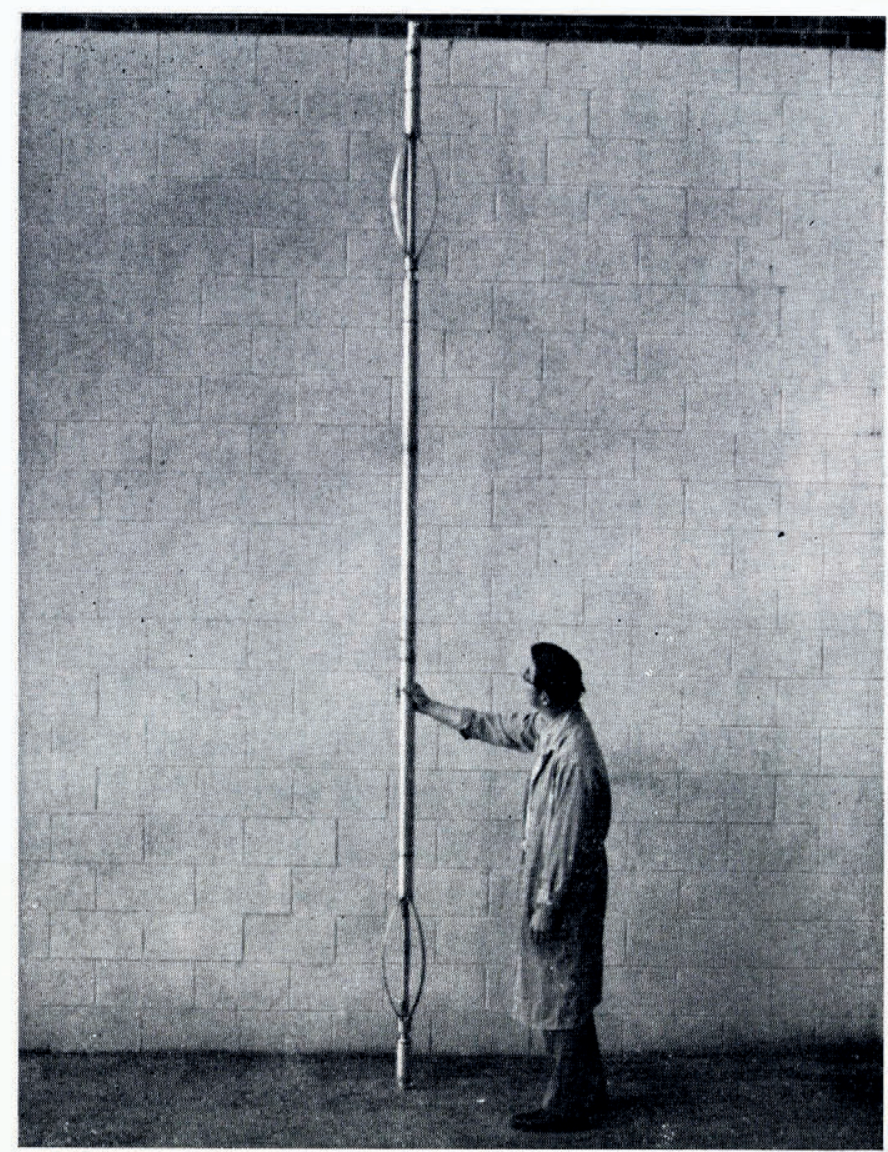

Fig. 2. Pressure-tight housing.

On the measurement run, 59 shots were taken at intervals of 50 and $100 \mathrm{ft}(\mathrm{I} 5.2$ and $30.5 \mathrm{~m})$ from $4960 \mathrm{ft}(\mathrm{I} 5 \mathrm{I} 2 \mathrm{~m})$ to $300 \mathrm{ft}(9 \mathrm{I} .5 \mathrm{~m})$. The inclinometer range was exceeded below $4835 \mathrm{ft}$ ( $1474 \mathrm{~m})$.

\section{REsults}

The very small plumb-bob deflections recorded in the upper $700 \mathrm{ft}(2 \mathrm{I} 3 \mathrm{~m})$ made azimuth determinations more difficult than at the lower depths. The slight changes in inclination agree with the results from the old "Byrd" drill hole (Gow, I963). Insignificant changes were noted after four years for the first $\mathrm{I}$ ooo $\mathrm{ft}(305 \mathrm{~m})$ in that hole.

The hole position as a function of depth was computed from the survey data by a technique known as the "balanced tangential method". For details of this method see Walstrom and others (1972). Measurements taken in 1975 were obtained at depths different from those of the 1968 measurements, so the 1975 data were shifted to obtain the $X$ and $Y$ coordinates at identical depths ( $Z$ coordinates) to the I968 data. Since the "balanced tangential method" assumes a constant inclination between measurement stations, linear interpolation was used to shift the 1975 data. A plan view of the ice movement is shown in Figures 4 and 5 for various vertical depths. The arrows indicate the magnitudes and azimuths of the displacements. 


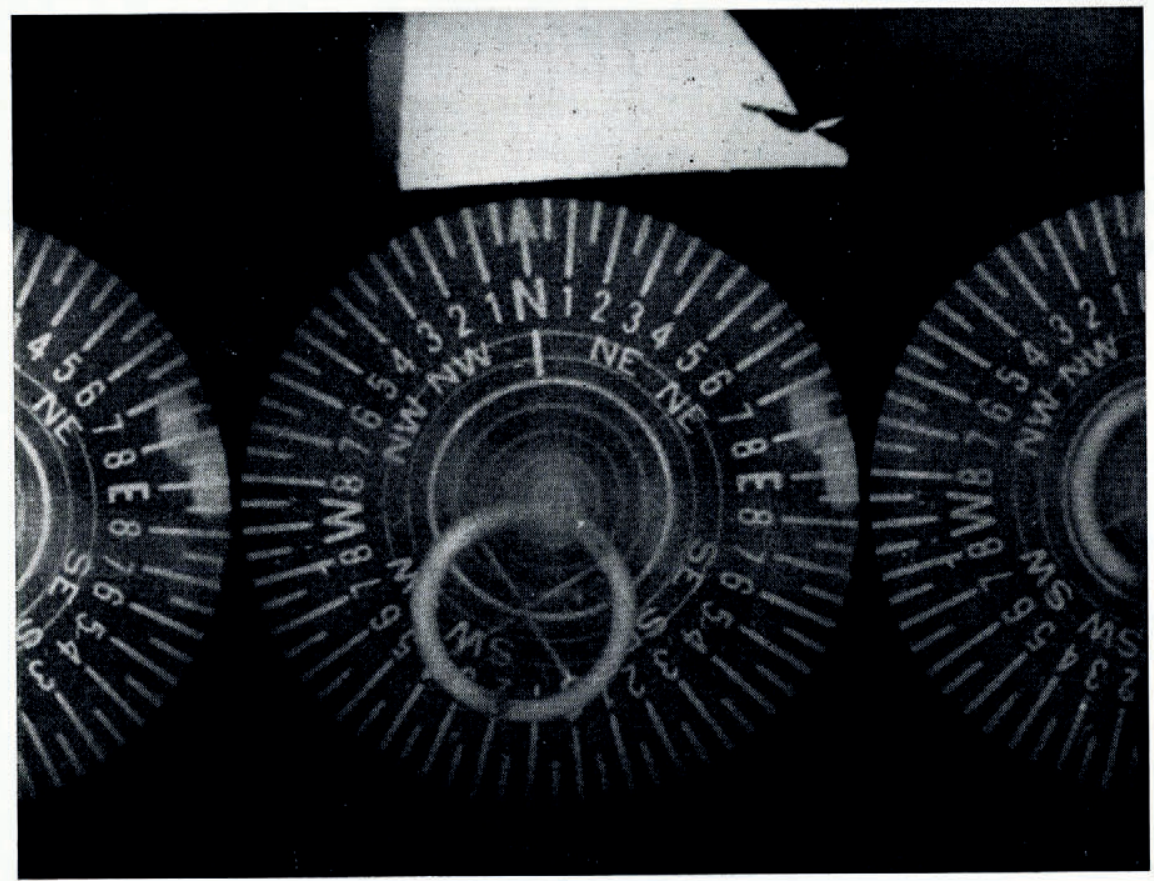

Fig. 3. Typical multiple-shot measurement exposure.

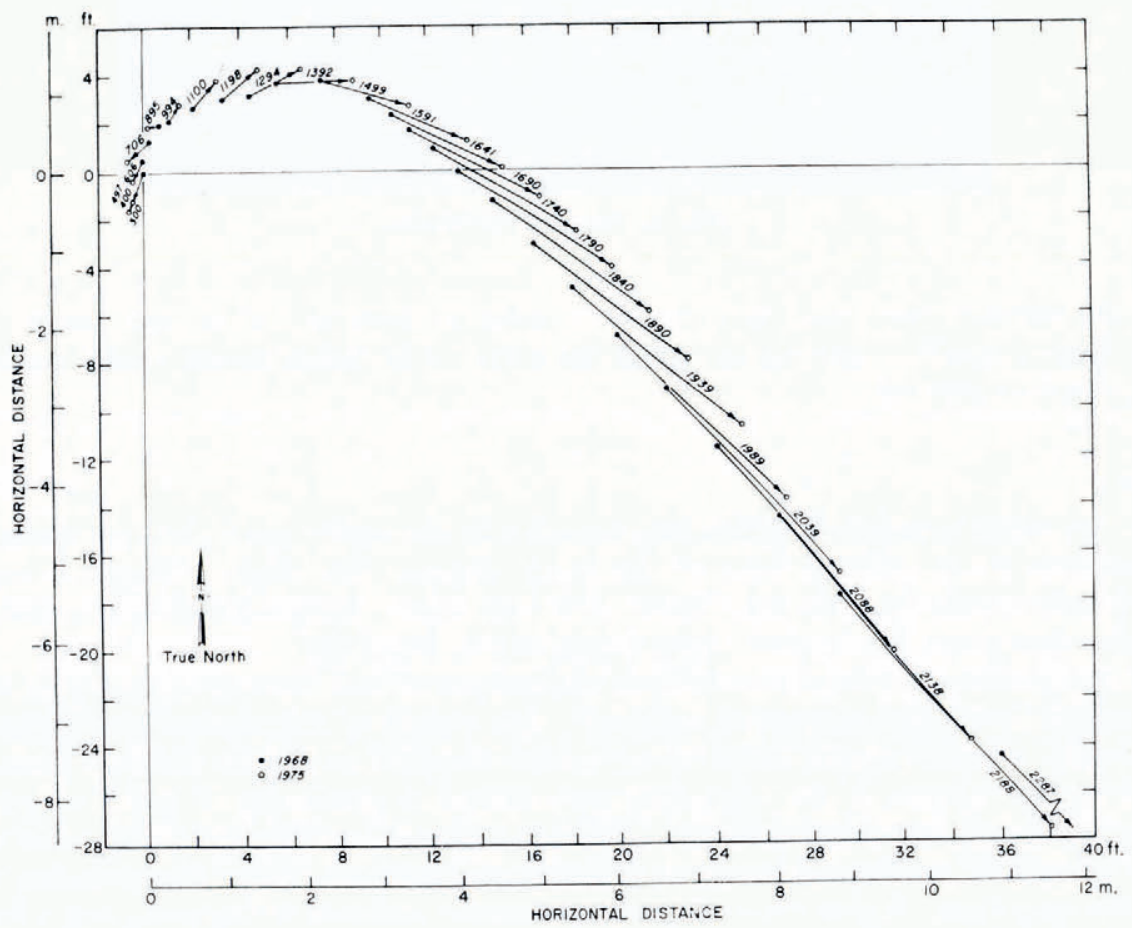

Fig. 4. Plan view of displacements to $2183 \mathrm{ft}(667 \mathrm{~m})$ depth, relative to top of hole casing. 
The resultant horizontal displacement of the hole with respect to the surface increases progressively with depth to a value of $5 \mathrm{I} .2 \mathrm{ft}(\mathrm{I} 5.6 \mathrm{~m}$ ) at the $4835 \mathrm{ft}$ ( $1757 \mathrm{~m}$ ) level, or about $7 \cdot 3 \mathrm{ft} /$ year $(2.23 \mathrm{~m} /$ year $)$. The interesting feature is the change in the direction of flow with depth, which indicates that the ice mass is undergoing a twisting action. Such a movement might be explained by a large irregularity in the bedrock topography such as the dome reported to be located about $3 \mathrm{~km}$ south of "Byrd" station (personal communication from I. M. Whillans). The surface movement at "Byrd" has been determined by Whillans to be

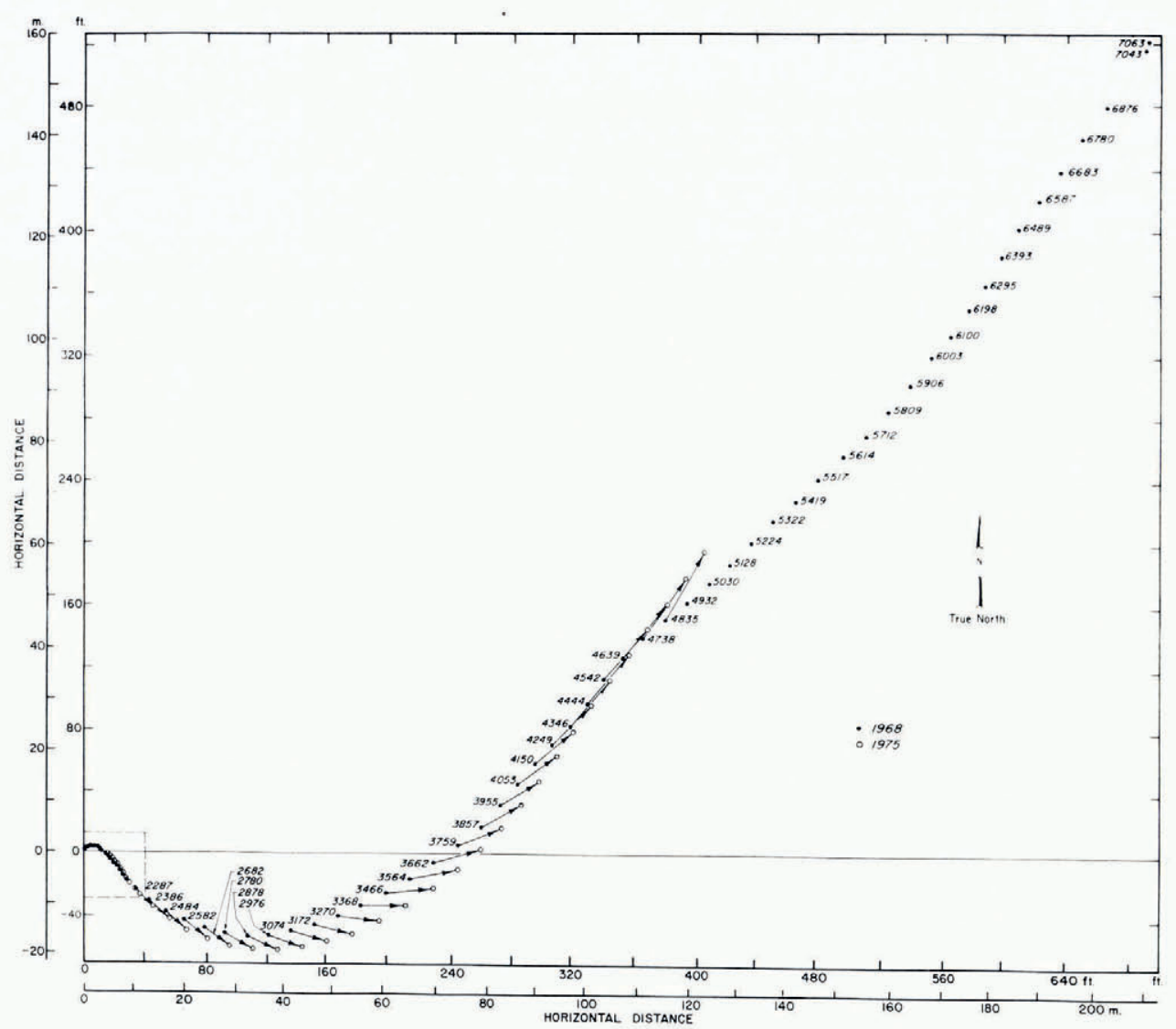

Fig. 5. Plan view of displacements to $4835 \mathrm{ft}(\mathrm{I} 474 \mathrm{~m})$, relative to top of hole casing. Section within dashed lines is shown on a larger scale in Figure 4.

in a generally south-westerly direction with an apparent rapid acceleration detected in the vicinity (Whillans, 1973). The general direction of displacements below about $3500 \mathrm{ft}$ ( 1 o6 $7 \mathrm{~m}$ ) agrees with this direction.

It is also interesting that the direction of inclination at the lower measured depths is in the proper direction to provide a possible explanation of the deviation of the original hole during drilling. A similar phenomenon was noted in the Camp Century, Greenland, drill hole (personal communication from B. L. Hansen). Unfortunately, the most interesting part of the hole in terms of ice movement is no longer accessible. 


\section{REcommendations}

It is recommended that another survey be conducted in 3-5 years, assuming that the station is still open. It is estimated that the drill hole site will be accessible for another 5 years. The hoist and cable were left intact. A power source such as a $7.5 \mathrm{~kW}$, three-phase generator is required. An up-dating of the survey equipment should be considered, particularly the inclination measuring device.

MS. received I8 August 1975

\section{REFERENCES}

Garfield, D. E. 1968. Drill hole measurements at Byrd station. U.S. Cold Regions Research and Engineering Laboratory. Internal Report 58.

Gow, A. J. 1963 . Results of measurements in the 309 meter bore hole at Byrd station, Antarctica. Fournal of Glaciology, Vol. 4 , No. 36, p. $771-84$.

Walstrom, J. E., and others. 1972. A comparison of various directional survey models and an approach to model error analysis, by J. E. Walstrom, R. P. Harvey and H. D. Eddy. Journal of Petroleum Technology, Vol. 24, August, p. 935-43.

Whillans, I. M. 1973. State of equilibrium of the west Antarctic inland ice sheet. Science, Vol. 182, No. 4III, p. $47^{6-79}$. 